\title{
NIEMCY ODESSY: OD UPRZYWILEJOWANIA DO UPODLENIA
}

$\mathrm{N}$ iemcy to naród posługujący się językiem niemieckim z grupy języków germańskich, pod względem wyznaniowym podzieleni są na katolików i protestantów, a zamieszkują nie tylko teren Republiki Federalnej Niemiec, lecz także są rozsiani po różnych kontynentach. Przyczyną tego jest między innymi ekspansja ludności niemieckiej (germańskiej) na wschód, która sięga jeszcze czasów średniowiecza i objęła m.in. terytoria zamieszkane przez Słowian i Bałtów. Warto zauważyć, iż spośród krajów (landów) wschodnich obecnego terytorium Niemiec jedynie Turyngia jest dawnym germańskim terytorium. Saksonia, Brandenburgia i Meklemburgia znajdują się na dawnych ziemiach słowiańskich?"

Ekspansja ludności germańskiej postępowała poprzez Prusy dalej na wschód. W jej wyniku już w XII w. na obecnym terytorium Łotwy i Estonii powstała grupa narodowościowa zwana Niemcami bałtyckimi². Stali się oni najstarszym reprezentantem tejże narodowości w państwie rosyjskim. Następnie w 1763 r. caryca Katarzyna wydała manifest zapraszający niemieckich kolonistów. Tym samym zaczęty rozwijać się kolonie: nad Wołgą, na Kaukazie, w północnej Syberii i Azji Środkowej, w Królestwie Polskim, w rejonie Petersburga i w samym Petersburgu oraz innych rosyjskich miastach europejskich na czele z Moskwą, Saratowem i Odessą, której został poświęcony niniejszy artykuł.
Mgr Sylwia TYSZKA jest doktorantką w Instytucie Kulturologii i Lingwistyki Antropocentrycznej na Wydziale Lingwistyki Stosowanej Uniwersytetu Warszawskiego. tyszka.sylwia@gmail.com

Skrypt do zajęć Zagadnienia narodowościowe Europy Środkowej i Batkanów,

M. Kowalski, Studium Europy Wschodniej, s. 10.

2 A. Topij, Ludność niemiecka wobec rusyfikacji guberni battyckich 1882-1905,

Bydgoszcz 1997, s. 5. 
Odessa to miasto leżące w południowej części Ukrainy nad Morzem Czarnym. Jest miastem stosunkowo młodym, ale stała się największym portem Ukrainy. Liczy przeszło 1000000 mieszkańców. Ze względu na fakt, iż zamieszkują ją osoby różnych narodowości - Rosjanie, Ukraińcy, Polacy, Niemcy, Żydzi, Mołdawianie, Ormianie, Grecy, Włosi i wielu innych - jest uważana za jedno z najbardziej „kosmopolitycznych” miast ukraińskich. Historia osady sięga czasów antycznych. W połowie IV w. p.n.e. Grecy założyli tu swoją kolonię-faktorię o nazwie Istrion. Następnie na tym miejscu powstała osada tatarska Kaczibej. W XV w. zdobyli ją i zniszczyli Turcy, którzy, odbudowując miasto, nazwali je Hadżibej. W wyniku wojny rosyjsko-tureckiej z lat 1787-1792 i na mocy pokoju w Jassach miasto znalazło się $w$ granicach państwa rosyjskiego. Pierwszym nieformalnym gubernatorem został jego zdobywca generał-major Jose de Ribas. Swoją obecną nazwę miasto otrzymało w 1795 r. od znajdującej się w pobliżu greckiej kolonii o nazwie Odessos. Formę męską tej nazwy zmieniono na żeńską "Odessa”, gdyż najprawdopodobniej chciano w ten sposób oddać cześć zdobywczyni miasta, Katarzynie $\|^{3}$. Prawa miejskie z kolei nadano w 1803 r. Miasto początkowo znajdowało się w guberni noworosyjskiej, którą następnie podzielono na trzy gubernie: jekatrynosłwską, taurydzką i mikołajewską, później przemianowaną na chersońską. Odessa weszła w skład tej ostatniej4.

Odessa szybko stała się najważniejszym portem czarnomorskim Rosji specjalizującym się $w$ handlu zbożem. Zadecydowały o tym korzystne położenie geograficzne, dobre zaplecze gospodarcze, a także popyt na eksportowane przez ten port artykuły oraz prohandlowa polityka władz. Port w Odessie został wybudowany - inaczej niż w Taganrogu, Chersoniu czy Mikołajewie - nie w głębi ujścia rzeki, lecz bezpośrednio nad Morzem Czarnym. Dzięki temu mógł przyjmować statki pełnomorskie przez cały rok. Aby zwiększyć obroty handlowe, w 1802 r. car Aleksander I uwolnit miasto od płacenia podatków i obowiązku kwaterowania wojsk. Cła zredukowano do 25\%, a w 1817 r. Odessa otrzymała status porto franko, tj. portu, w którym nie pobiera się opłat celnych od przewożonych towarów ${ }^{5}$.

Gubernatorem guberni noworosyjskiej i jednocześnie pierwszym burmistrzem Odessy został francuski książę Armand-Emanuel du Pleiss de Richelieu. Uczynit on z niej nowoczesny ośrodek handlowy z prężnym portem i monumentalnymi gmachami. On także sprowadził tu osadników i przedsiębiorców z różnych części Europy, w wyniku czego miasto stało się swoistym tyglem narodowościowym. Obok Rosjan mieszkali tu Żydzi, Grecy, Bułgarzy, Ormianie, Niemcy, Włosi, Francuzi i wielu innych ${ }^{6}$. Co do osadnictwa przedstawicieli narodowości niemieckiej należy stwierdzić, iż nie miało ono monolitycznego charakteru. Z jednej strony jej przedstawiciele osiedlali się w samym mieście, gdzie otwierali zakłady rzemieślnicze lub duże zakłady przemysłowe. Z drugiej strony emigranci otrzymywali także nadziały ziemi w okolicach miasta, gdzie głównie prowadzili gospodarstwa rolne.

3 N. Helling, B. Schulze, Invitation to Odessa. Guide to Ukraine, 2005, s. 2.

4 D. Brandes, Von den Zaren adoptiert. Die deutschen Kolonisten und Balkansiedler in Neurußland und Bessarabien 1751-1914, Oldenburg Verlag, München 1993 s. 59.

5 M. Trąbski, Odessa i stepy Nowej Rosji opisane przez Juliana Ursyna Niemcewicza w 1818 r., w: Polacy na południowej Ukrainie i Krymie, red. T. Ciesielski, E. Czapiewski, W. Kusznir, Odessa-Opole-Wrocław-Olsztyn 2007, s. 337.

6 A. Grossman, Krym. Pótwysep rozmaitości ... oraz Lwów, Kijów Odessa, Kraków 2007; A. Kappeler, Kleine Geschichte der Ukraine, München 1994, s. 108. 
Początki osadnictwa niemieckiego w Odessie przypadły na czas wojen napoleońskich, które doprowadziły do gospodarczego wyniszczenia państw niemieckich i zerwania bardzo luźnych więzi między nimi. Wskutek tego przybrała na sile zapoczątkowana przez Katarzynę II fala emigracyjna z Niemiec do Rosji. W jej wyniku już pod koniec XVIII w. liczba Niemców na południu Ukrainy wyniosła 5500, czyli 0,4\% ludności obszaru8. Politykę swojej babki kontynuował car Aleksander I, inicjując program kolonizacji terenów leżących nad Morzem Czarnym. Centrum tejże kolonizacji miała się stać Odessa.

W mieście tym rosyjscy poddani osiedlali się niechętnie ze względu na nie najlepsze stosunki z Turcją, ze strony której obawiano się rozpoczęcia kolejnej wojny. Wchodziła tu także w grę konkurencja innych miast, głównie Chersonia i Mikołajewa. Z tego też względu, aby przyciągnąć obcokrajowców nadawano im status kolonisty. Łączyło się z tym otrzymanie 60 dziesięcin ziemi, jak również szereg przywilejów: wolność wyznania, zwolnienie ze służby wojskowej, nieoprocentowane pożyczki na rozpoczęcie działalności, ulgi podatkowe i własny samorząd. W zamian za to Niemcy mieli się zająć zagospodarowaniem tych ziem. W wyniku tych działań masowe zasiedlenie Odessy i okolicznych terytoriów niemieckimi kolonistami rozpoczęło się w 1803 r., gdy przybyły tu pierwsze transporty z Ulm. Pierwsi koloniści pochodzili głównie z Wirtembergii, gdyż tamtejsza konstytucja dawała im prawo wyjazdu. Były wśród nich też osoby z Badenii i Prus ${ }^{9}$. Rosyjskie władze nie zapewnity im jednak odpowiednich warunków do przetrwania zimy. Brakowało też odpowiedniej opieki lekarskiej. Spowodowało to, iż wiele osób zmarło, a spora część spośród tych, którzy przeżyli, wróciła do kraju ${ }^{10}$.

W celu opieki nad kolonistami w 1800 r. został powołany tzw. Komitet Opiekuńczy dla Kolonistów Południowej Rosji (Fürsorgekommittee für die Kolonisten Südrußlands, Popečitel'nyj komitet o kolonistach Južnogo kraja), który w latach 1833-1871 miał swoją siedzibę w Odessie. Z rozkazu Richelieu pierwsze kolonie zakładano w pobliżu miasta, aby zapewnić rynki zbytu na ich produkty ${ }^{11}$. Kolonie niemieckie powstałe wokół Odessy otrzymały nazwę Odesskowo wodworienja, a w jego skład weszły następujące okręgi: Liebental (11 kolonii), Berezan (13 kolonii), Kuczugan (6 kolonii), Glückstal (5 kolonii) ${ }^{12}$. Ten system okręgów kolonialnych istniał do wprowadzenia reformy rolnej w 1871 r., na mocy której koloniści otrzymali status osadników-właścicieli (poselian-sobstwiennikow). Na początku XIX w. w Odessie powstała także kolonia rzemieślnicza składająca się z 42 rodzin $^{13}$.

Zgodnie z danymi spisu powszechnego z 1897 r. w Odessie mieszkało 10000 Niemców, czyli 2,5\% ludności miasta ${ }^{14}$, a język niemiecki stanowił czwarty język w mieście po rosyjskim, jidysz i polskim. W guberni chersońskiej, do której należała Odessa, udział ludności niemieckiej w 1795 r. wyniósł 0,8\%, w 1815 r. - 3,5\%, w 1857 r. - 3,9\%, a w samym obwodzie odeskim prawie $12 \%^{15}$. Udział klas wyższych, czyli szlachty, inteligencji

7 Z. Zieliński, Niemcy. Zarys dziejów, Warszawa 1998, s. 50

8 N.A. Sevčuk, Die Deutsche evangelisch-lutherische Gemeinde Odessas im 19. Jahrhundert, w: Odessa. Kapitel aus Kulturgeschichte, red. Ch. Schmalzl, Regensburg 1998, s. 71-77.

9 D. Brandes, Von den Zaren adoptiert, s. 60-61, 252

10 P. Herlighy, s. 261.

11 E.G. Plesskaya-Zebol'd, Nemcy w Pričernomorja: istoria i kultura. XIX-XX ww., w: Nemcy Pričernomorja, Odessa 2003, s. 5; A.N. Keller, Izmienienja w nemeckoj toponimi Odesskovo regiona, w: Nemcy Odessy i odesskogo regiona, red. E.G. Plesskaya-Zebol'd, Odessa 2003, s. 330

12 E.G. Plesskaya-Zebol'd, Nemcy w Pričernomorja: istoria i kultura, s. 5.

13 T. Penter, Odessa 1917: Revolution an der Peripherie, Köln-Böhlau 2000; A.N. Keller, Izmienienja w nemeckoj toponimi Odesskovo regiona, w: Nemcy Odessy i odesskogo regiona, s. 330.

14 E.G. Plesskaya-Zebol'd, Odesskie Nemcy 1803-1920, Odessa 1999, s. 14.

15 N.A. Sevčuk, Die Deutsche evangelisch-lutherische Gemeinde Odessas im 19. Jahrhundert, w: Odessa. Kapitel aus Kulturgeschichte, s. 71 
i obywateli honorowych wynosił zaledwie 7\%. Liczba niemieckich kupców przewyższała inne grupy etniczne o 3\%, a chłopstwa była o 30\% mniejsza niż wśród Rosjan i Ukraińców. Jedna czwarta Niemców reprezentowała warstwę drobnomieszczańską. Spośród Niemców mieszkających w Odessie co trzeci nie był obywatelem Rosji16, 3400 było poddanymi austriackimi, 2700 obywatelami Cesarstwa Niemieckiego, a resztę stanowili poddani rosyjscy ${ }^{17}$. W latach 1835-1848 liczba rodzin niemieckich w Odessie zwiększyła się z 90 do 431, gdyż zaczęły się tu osiedlać także osoby wcześniej ulokowane w koloniach położonych w okolicach miasta ${ }^{18}$.

\section{ŻYCIE RELIGIJNE NIEMCÓW ODESKICH}

Przybyli do Odessy Niemcy reprezentowali dwie główne grupy wyznaniowe: protestantów i katolików. Ich liczba według spisu z 1897 r. wynosiła, odpowiednio, 7000 i 2000 osób. Na podstawie tego podziału wyznaniowego powstały tu dwie niemieckie kolonie: górna - luterańska i dolna - katolicka, położona przy ulicy Rzemieślniczej (Remieslennoj) ${ }^{19}$. W kolonii luterańskiej w 1827 r. odbyło się wyświęcenie luterańskiego kościoła pod wezwaniem świętego Pawła. Jego budowa rozpoczęła się w 1824 r. na podstawie planu przygotowanego przez architekta Karla Franka Boffo. W tym czasie parafia liczyła 400 rodzin, wśród których przeważały rodziny rzemieślników. Było ich 300. Resztę stanowiły rodziny kupców, wojskowych, naukowców i urzędników. Pod koniec lat 80. XIX w. parafia liczyła już 4000 osób, wśród których rzemieślnicy ciągle zachowali przewage, stanowiąc jedną trzecią wszystkich wiernych ${ }^{20}$. Krótko po wyświęceniu kościoła w 1830 r. ówczesnemu pastorowi zarzucono skandaliczne zachowanie i pozbawiono go funkcji. Na nowego pastora powołano Karla Fletnitzera, który sprawował swoją funkcję do 1868 r. i bardzo przyczynił się do rozwoju edukacji w parafii. Będąc pastorem, jednocześnie sprawował funkcję dyrektora szkoły świętego Pawła. Dzięki jego staraniom placówka ta została przekształcona w progimnazjum ${ }^{21}$.

W trakcie pełnienia posługi przez pastora Fletnitzera przy kościele świętego Pawła wybudowano ośrodek dla starców i ubogich. Jednakże w 1841 r. doszło tu do konfliktu. Był on związany z faktem, iż od początku swego istnienia parafia protestancka w Odessie skupiała nie tylko wiernych wyznania ewangelicko-augsburskiego, lecz także ewangelicko-reformowanego. Ci drudzy byli nieliczni, ale za to bardzo zamożni. Z czasem liczba wiernych powiększyła się, a pastor Fletnitzer zdecydował, iż jest mu potrzebny pomocnik. W związku z tym reformaci poprosili o wyznaczenie drugiego pastora, który prowadziłby nabożeństwa tylko dla nich. Na to kategorycznie nie zgodził się pastor Fletnitzer, gdyż obawiał się, iż pozbawi go to części dochodów. Konflikt stał się na tyle poważny, że wspólnota ewangelicko-reformowana zdecydowała się opuścić wspólnotę ewangelicko-augsburską i założyć własną. W wyniku tego liczba wiernych w kościele świętego

\section{-....}

16 T. Penter, Odessa 1917: Revolution an der Peripherie, Köln-Böhlau 2000; A.N. Keller, Izmienienja w nemeckoj toponimi odesskovo regiona, w: Nemcy Odessy i odesskogo regiona, s. 63.

17 P. Herlighy, s. 261.

18 D. Brandes, German Colonists in Southern Ukraine up to the Repeal of the Colonial Statute, w: GermanUkrainian Relations in Historical Perspective, red. H.-J. Torke, J.-P. Himka, Edmonton-Toronto 1994, s. 21.

19 E.G. Plesskaya-Zebol'd, Odesskije Nemcy 1803-1920, Odessa 1999, s.13.

20 N.A. Sevčuk, Die Deutsche evangelisch-lutherische Gemeinde Odessas im 19. Jahrhundert, w: Odessa. Kapitel aus Kulturgeschichte, s. 75.

21 Cerkownyj centr sw. Pawla. Odessa, red. K.-J. Ropke, Odessa-Monachium 2002, s. 9. 
Pawła zmniejszyła się w 1845 r. do 2516 osób²2. Sam pastor Fletnitzer zakończył służbę w 1868 r. Na stanowisku dyrektora szkoły św. Pawła zastąpił go G. Kowalzig, natomiast nowym pastorem obrano Herberta Binemanna ${ }^{23}$. W trakcie posługi tego pastora parafia dostała pozwolenie na wydawanie własnego miesięcznika pt. "Christlicher Volksbote" („Christianskij narodnyj westnik") ${ }^{24}$.

Należy wspomnieć, iż oprócz Niemców parafię katolicką tworzyły także osoby innych narodowości: Francuzi, Włosi, Polacy²5. Ogólna liczba katolików w guberni chersońskiej w roku 1862 wyniosła 29523 osoby. Zwiększenie tej populacji o 2799 osób nastąpito w latach 1862-1864 oraz w latach 1866-1869, kiedy liczba katolików wzrosła o 3468 osób ${ }^{26}$. Parafia powstała w roku 1796, a budowę kościoła rozpoczęto w 1801 r. Pierwszym proboszczem został Niemiec pochodzący z Bawarii, I. Lindl. W 1823 r. parafia liczyła 4236 wiernych, wśród których najliczniejszą grupę stanowili Niemcy - 1382, na drugim miejscu byli Włosi - 1328, na trzecim Polacy - 890, a na czwartym Francuzi - 680 osób. Ze względu na zwiększającą się liczbę wiernych wyznania katolickiego w 1848 r. utworzono biskupstwo z siedzibą w Chersoniu. Jednak w związku ze sprzeciwem prawosławnego biskupa Chersonia, siedzibę diecezji katolickiej przeniesiono do Tyraspola, a w jej skład weszły gubernie: chersońska, besarabska, jekaterynosławska, saratowska, taurydzka, astrachańska oraz Zakaukazie ${ }^{27}$.

Wraz z założeniem biskupstwa w Tyraspolu, w Odessie został utworzony dekanat. Prałatem został ksiądz G. Rozytowicz, który rozpoczął budowę nowego budynku kościoła katolickiego w Odessie przy ulicy Jekatyrinskiej. Prace zakończono w 1853 r., a na patrona kościoła wybrano św. Klemensa. W spisie powszechnym z 1897 r. 24218 mieszkańców zadeklarowało wyznanie katolickie. W grupie tej największą część stanowili Polacy - 16 875, na drugim miejscu byli Niemcy - 2217, następne miejsca zajmowali Francuzi - 850 i Włosi 673 osoby²8.

Od początku XX w. coraz aktywniej działała niemiecka część wspólnoty. W 1906 r. zaczęła wydawać własną gazetę pt. „Deutsche Rundschau”, w której przedstawiano problemy niemieckich katolickich kolonii oraz wspólne problemy Kościoła katolickiego w Rosji i w Niemczech ${ }^{29}$. Niemcy sprawowali także wysokie funkcje kościelne w tej diecezji. Na przykład na ostatniego biskupa tyraspolskiego został obrany Niemiec - Josif Kessler, który w 1918 r. przeniósł swoją siedzibę do Odessy. Biskupstwo istniało tu do 1924 r., a jego zwierzchnik, w związku z prześladowaniami Kościoła katolickiego w ZSRR, wyjechał do Niemiec ${ }^{30}$.

23 N.A. Sevčuk, Die Deutsche evangelisch-lutherische Gemeinde Odessas im 19. Jahrhundert, w: Odessa. Kapitel aus Kulturgeschichte, s. 77.

24 E.G. Plesskaya-Zebol'd, Odesskije Nemcy 1803-1920, s. 188.

25 Tamże, s. 208

26 L. Zasztowt, Zsytka i przesiedlenia ludności polskiej z zachodnich guberni w głąb cesarstwa rosyjskiego po powstaniu styczniowym, „Przegląd Wschodni”, Warszawa 1998, z. 2(18), s. 260.

27 A. Dobroer, Religioznoe služenje pol'skich sviaščennikov v južnoj Ukrainie, red. T. Ciesielski, E. Czapiewski, A. Korytko, W. Kusznir, H. Stroński, Polacy na Południowej Ukrainie XVII-XVIII wiek, Olsztyn-Opole-Wroctaw-Odessa 2006, s. 40.

28 E.G. Plesskaya-Zebol'd, Odesskije Nemcy 1803-1920, s. 208-222.

29 Tamże.

30 A. Dobroer, Religioznoe služenje pol'skich sviaščennikov v južnoj Ukrainie, s. 40.
} 
Do Niemców należały najlepsze domy handlowe w mieście, zakłady produkcji maszyn rolniczych i 9 fabryk dostarczających 85\% całkowitej przemysłowej produkcji miasta ${ }^{31}$. Pierwszy niemiecki cech powstał już w 1805 r., a w 1826 r. było ich tu już 13. W 1898 r. znajdowało się w Odessie 1513 przedsiębiorstw. Około 90 z nich zostało założonych przez Niemców ${ }^{32}$. Jednymi z pierwszych były zakłady produkcji maszyn rolniczych Falka-Restela i wytwórnia wyrobów stalowych Gustawa Berndta. Z kolei warsztat J. Höhna stał się największym wytwórcą pługów w cesarstwie rosyjskim³3. Do grupy ważniejszych zakładów wytwórczych należała także odlewnia i fabryka maszyn Bellino-Fenderich. W 1884 r. był to największy zakład nie tylko w Odessie, lecz także na południu Rosji, gdzie dostarczał dwie trzecie miejskich wyrobów odlewniczych ${ }^{34}$. Już na początku lat 20. XIX w. Karl Haaz założył warsztaty produkcji instrumentów muzycznych, które w 1865 r. zostały nagrodzone złotym medalem na targach w Moskwie. Jeszcze bardziej zasłużonym przedsiębiorcą był największy odeski producent mydła, W. Sanzenbacher. Jego produkty pod koniec XIX W. odznaczono złotymi medalami na targach w Londynie, Brukseli, Kolonii i Madrycie ${ }^{35}$.

Z Odessą związani byli także wielcy posiadacze ziemscy - rodzina Falz-Fein. Założyciel fortuny Johann Fein przybył do Rosji, otrzymał status kolonisty i zajął się hodowlą owiec. W 1814 r. otworzył w Halbstadt własną fabrykę sukna. Jego syn Friedrich w 1849 r. wybudował w Chersoniu przędzalnię wełny. Z czasem została ona uznana za wzorowego hodowce. Na targach rolnych w Symferopolu w 1846 r. otrzymał złoty medal za wyhodowanie najlepszej rasy merynosów. W 1856 r. kupił posiadłość Askania Nowa, znajdującą się w obwodzie chersońskim, gdzie hodował około 42000 sztuk bydła i 275000 sztuk owiec o wełnie najlepszej jakości. Gdy córka Friedricha, Elizabeth, weszła za mąż za Johana Gottlieba Pfalza, rodzina przybrała nazwisko - Falz-Fein ${ }^{36}$. Spadkobierca Friedricha Falz-Feina, także Friedrich, studiował nauki przyrodnicze na uniwersytecie w Dorpacie i w swojej posiadłości założył ogród zoologiczny oraz rezerwat przyrody. Obszar ten po nacjonalizacji ziemi przez bolszewików został uznany za stepowy obszar chroniony. Nawet w granicach obecnego państwa ukraińskiego otrzymał status parku narodowego, do czego w znacznym stopniu przyczyniła się rodzina Falz-Feinów ${ }^{37}$. Z rodziną tą jest związany także jeden z zabytków Odessy, dom znajdujący się przy ulicy Gogola. Znajdują się na nim rzeźby przedstawiające dwóch mężczyzn dźwigających kulę ziemską. Rodzina mieszkała tu do kwietnia 1919 r., kiedy ostatnim statkiem, jaki opuszczał Odessę, udali się do Konstantynopola, a stamtąd do Berlina ${ }^{38}$.

Integracji Niemców ze społecznością miasta nic nie stało na przeszkodzie. Byli oni często członkami rady miejskiej, różnego rodzaju komitetów handlowych, a nawet przez 20 lat stali na czele komitetu giełdowego ${ }^{39}$. Wnieśli także swój wkład w pomoc ubogim,

31 T. Penter, Odessa 1917: Revolution an der Peripherie, Köln-Böhlau 2000, s. 64.

32 N.A. Sevčuk, Die Deutsche evangelisch-lutherische Gemeinde Odessas im 19. Jahrhundert, w: Odessa. Kapitel aus Kulturgeschichte, s. 71.

33 G. Sticker, Deutsche Geschichte im Osten Europas. Russland, Berlin 1997, s. 85.

34 E.G. Plesskaya-Zebol'd, Wkład Niemcev v promyszlennoje razwitje Odessy s popytkoj rassmotrenja kulturologiceskogo aspektu problemy, w: Nemcy Odessy i odesskogo regiona, s. 140-148.

35 E.G. Plesskaya-Zebol'd, Odesskije Niemcy 1803-1920, s. 208-222.

36 W języku niemieckim połączenie literowe 'Pf' wymawia sie jak ' $f$ ', a w związku z tym, iż rodzina ta przebywała w słowiańskim otoczeniu to zdecydowała się na zmianę pisowni nazwiska tak, aby miejscowi mogli je właściwie wymawiać.

37 Deutsche und deutsche Kultur in der Ukraine, red. W. Smolij, Kijów 2008, s. 48, Brandes D., Von den Zaren adoptiert, s. 403-405.

38 J. Bauman, U. Moosburger, Odessa. Facetten einer Stadt im Wandel, Regensburg 2003, s. 62

39 T. Penter, Odessa 1917: Revolution an der Peripherie, s. 64. 
zakładając niemieckie towarzystwo charytatywne - Deutsche Wohltätigkeitsgesellschaft (Germanskoje blagotvoritel'noe obščestvo). Bankier A.E Mas wspierał swoimi ofiarami miejski przytułek dla bezdomnych, a za pieniądze znanego przemysłowca W. Sanzenbachera w 1894 r. wybudowano w Odessie cyrk, w którym do chwili obecnej odbywają się przedstawienia ${ }^{40}$. Niemcy założyli w Odessie także wiele klubów i stowarzyszeń takich, jak: Niemieckie Stowarzyszenie Gimnastyczne (Deutscher Turnverein), Niemieckie Stowarzyszenie Pomocy (Deutscher Hilfsverein), Stowarzyszenie Rzemieślnicze (Gewerbeverein) oraz stowarzyszenie Harmonia. Za organizację uroczystości kościelnych odpowiedzialne było stowarzyszenie Bach-Verein ${ }^{41}$.

OKOLICE ODESSY

W koloniach znajdujących się pod Odessą koloniści musieli zmierzyć się z wieloma trudnościami, takimi jak praca w trudnych warunkach klimatycznych, do których nie byli przyzwyczajeni. Dodatkowym problemem było to, iż nie mieli zapewnionej żadnej opieki medycznej, co było przyczyną dużej śmiertelności². Mimo wszystko dalej tu przybywali tworząc nowe kolonie: Großliebental, Kleinliebntal, Lustdorf, Freudental, Franzfeld, Peterstal, Josefstal, Mariental, Neuburg, Aleksanderhilf i wiele innych ${ }^{43}$. Po około 20 latach od przybycia pierwszych kolonistów rozpoczął się proces tworzenia tzw. koloniicórek (Tochterkolonien, dočernyje kolonii). Pierwszą była kolonia Neufriedental w okręgu liebentalskim ${ }^{44}$. W wyniku tego procesu zaczęła się zwiększać liczba ludności niemieckiej w okolicach Odessy. Pod koniec XIX w. mieszkało tam 62658 niemieckich kolonistów, co stanowiło 10\% ludności okręgu. Niemcy byli także właścicielami największej ilości ziemi: przed wybuchem I wojny światowej w ich posiadaniu znajdowało się 38\% całkowitej powierzchni okręgu, a do Ukraińców należało 15\% ${ }^{45}$.

Istotną formą działalności rolniczej niemieckich kolonistów była hodowla owiec i koni, na przykład w kolonii Glückstal znajdowała się wspólnotowa owczarnia. Hodowano tu owce szlachetnych gatunków, głównie hiszpańskich. Niemcy hodowali także wschodniofryzyjskie krowy przywiezione z Niemiec. Mleko i produkty mleczne, głównie masło, sprzedawano następnie w Odessie. Niemcy zajmowali się też sadownictwem, uprawą winorośli i tytoniu oraz pszczelarstwem. Regionalną sławę zdobyło wytwarzane przez Niemców wino, którego receptura pochodziła z Niemiec. W licznych browarach wytwarzano piwo ${ }^{46}$. W koloniach otwierali swoje zakłady rzemieślnicy: kowale, szewcy, stolarze. W 1882 r. w niemieckich koloniach okręgu odeskiego pracowało 22802 rzemieślników,

40 N.A. Sevčuk, Die Deutsche evangelisch-lutherische Gemeinde Odessas im 19. Jahrhundert, w: Odessa. Kapitel aus Kulturgeschichte, s. 77.

41 G. Stricker, Deutsche Geschichte im Osten Europas. Russland, Berlin 1997, s. 48.

42 D. Brandes, Von den Zaren adoptiert, s. 215.

43 Nazwy te można w następujący sposób przettumaczyć na język polski: Wielka Dolina Miłości, Mała Dolina Miłości, Wieś Ochoty, Dolina Radości, Pole Franciszka, Dolina Piotra, Dolina Józefa, Dolina Marii, Nowy Gród, Pomoc Aleksanda. Po wysiedleniu Niemców miejscowościom tym nadano nazwy rosyjskie, a po 1991 r. ukraińskie. Oto część z nich Peterstal - ros. Petrodolinskoje, Petrodolynilivka, Mariental - ros. Marianowa, ukr. Marianiwka, Neuburg - ros. Novogadovka, ukr. Novogradivka, Aleksanderhilf - ros. Dobroaleksandrovka, ukr. Dobroaleksandrivka.

44 E.G. Plesskaya-Zebol'd, Nemcy Pričernomorja: istoria i kultura. XIX-XX wW., w: Nemcy Pričernomorja, Odessa 2003, s. 5; A.N. Keller, Izmienienja w nemeckoj toponimi Odesskovo regiona, w: Nemcy Odessy i odesskogo regiona, s. 332.

45 T. Penter, Odessa 1917: Revolution an der Peripherie, s. 64

46 K.-M. Gauß, Niemcy na peryferiach Europy. Wędrówki przez Litwę, Spisz i brzegiem Morza Czarnego, Wotowiec 2000, s. 169. 
najwięcej w koloniach Selz, Großliebental i Landau ${ }^{47}$. Zakładano tu także zakłady wytwórcze. W Großliebental największymi zakładami były młyn i cegielnia. W koloniach niemieckich działało jeszcze 14 innych młynów. Dodatkowo w 1843 r. w kolonii Großliebental otwarto zakład wodoleczniczy. Po 4 latach od otwarcia przyjmował on 85 kuracjuszy ${ }^{48}$.

Ważną rolę w życiu kolonistów odgrywał Kościót. Zasadniczo należeli oni do dwóch grup wyznaniowych: katolickiej i protestanckiej. Ludność kolonii okręgu kuczugańskiego była katolicka. W okręgu berezańskim katolicy zamieszkiwali kolonie Karlsruhe, Landau, Speyer, München, Rastatt, Kateriniental, Selz, Neurastadt, a luteranie i kalwini - kolonie Worms i Rorbach. W okręgu liebentalskim ludność była wymieszana pod względem wyznaniowym. Kościoły budowano w centrum kolonii, a ich architektura zawierała tradycyjne elementy niemieckiego budownictwa sakralnego. W parafiach, szczególnie protestanckich przewidujących znajomość Pisma Świętego, dużą wage przykładano do organizacji szkolnictwa. Szkoły powstawały już w pierwszych latach po przybyciu Niemców na te tereny. Były budowane i utrzymywane na koszt członków danej parafii. Nauczyciel jednocześnie sprawował funkcję pomocnika pastora. Początkowo program nauczania obejmował naukę czytania, pisania, liczenia, śpiew pieśni religijnych oraz czytanie Pisma Świętego. W drugiej połowie XIX w. włączono do niego także język rosyjski i historię Rosji. W celu przygotowania kadr nauczycielskich tworzono kolegia dla nauczycieli. W 1869 r. otwarto kolegia pedagogiczne w koloniach Großliebental i Neufriedental. To drugie w 1907 r. zostało przeniesione do kolonii Landau. W kolonii Großliebental w 1905 r. otwarto gimnazjum dla dziewcząt ${ }^{49}$.

\section{PRZYWILEJE LUDNOŚCI NIEMIECKIEJ}

Niemcy w carskim imperium cieszyli się licznymi prawnymi, gospodarczymi i kulturalnymi przywilejami, jakich nie posiadali nawet sami Rosjanie. W ten sposób władze mogły liczyć na ich lojalność. Z czasem jednak ta uprzywilejowana pozycja zaczęła stopniowo ulegać ograniczeniu. W 1871 r. w wyniku przeprowadzenia w Rosji reform społeczno-ekonomicznych zostali zrównani w prawach z innymi grupami ludności. Następnie w 1874 r. został im odebrany przywilej zwolnienia z powszechnego obowiązku służby wojskowej. W wyniku tego wielu menonitów ${ }^{50}$ emigrowało do Ameryki ${ }^{51}$. Nieprzychylna wobec Niemców polityka przybrała na sile za panowania Aleksandra III, znanego ze swojego antyniemieckiego nastawienia52. Za jego rządów na podstawie ustawy z 17 maja 1887 r. szkoły niemieckie zostały podporządkowane rosyjskiemu Ministerstwu Oświaty. Wiązało się z tym zastąpienie języka niemieckiego w tych placówkach językiem rosyjskim³ ${ }^{53}$

47 Nazwy niemieckich kolonii nawiązywały do miejsc, z których przybyli koloniści. W tym przypadku Landau to miasto leżące w Nadrenii.

48 D. Brandes, Von den Zaren adoptiert, s. 214, 223, 251, 273.

49 K.-M. Gauß, Niemcy, s. 218

50 Menonici to przedstawiciele wyznania będącego jednym z odłamów anabaptyzmu. Przewidywało ono: chrzest młodzieży od 14 lat jako świadomej decyzji i wiary w Chrystusa, możliwość wykluczenia z gminy menonickiej grzeszników, wybór pastorów przez wiernych oraz całkowity zakaz noszenia i używania broni. Z tego względu wprowadzenie powszechnego obowiązku służby wojskowej wywołało tak wielkie poruszenie wśród nich.

51 T. Iwanowa, Nimecka kolonizacja pivdennovo pričernomorja, w: Region nadczarnomorski w polityce europejskiej, red. T. Ciesielski, E. Czapiewski, W. Kusznir, Odessa-Opole-Wrocław 2008.

52 A. Topij, Ludność niemiecka wobec rusyfikacji guberni bałtyckich, s. 8.

53 M. Cygański, Niemieckie mniejszości narodowe w państwach Europy Środkowo-Wschodniej w latach 19451995, Opole 2000, s. 107. 
Następnie w latach 1915-1917 zostały wydane tak zwane "ustawy likwidacyjne" (Liquidationsgesetze), które przewidywały wywłaszczenie niemieckich posiadaczy ziemskich, przedsiębiorców i przemysłowców. Na zachodnich terenach przygranicznych postanowienia ustawy były surowo egzekwowane i doprowadziły do wywózki na Syberię przeszło 100000 Niemców. W Odessie jej skutki miały stosunkowo łagodny przebieg. Żaden niemiecki przedsiębiorca nie został wywłaszczony, a spośród kolonistów okręgu odeskiego pozbawiono ziemi tylko $5 \%$ właścicieli ${ }^{54}$.

\section{NIEMCY W ODESSIE W CZASIE I I / WOJNY ŚWIATOWEJ}

Wiadomość o obaleniu monarchii w 1917 r. została przyjęta z ulgą przez niemiecką ludność Odessy. Powołanie nowego zgromadzenia ustawodawczego obudziło w nich nadzieję na zakończenie bezpodstawnej dyskryminacji. Odpowiadając na wezwanie Rządu Tymczasowego do narodów Rosji, zdecydowali się wziąć udział w ustanowieniu w kraju demokracji i w marcu 1917 r. utworzyli w Odessie Wszechrosyjski Związek Niemców Rosji (Wserossijskij sojuz russkich nemcew). W pierwszym zjeździe organizacji w maju 1917 r. uczestniczyło przeszło 2000 niemieckich delegatów z południowych guberni kraju. Ustalono wtedy, iż najlepszą formą państwową dla Rosji będzie republika z wybieranym parlamentem i podporządkowanym mu prezydentem. Szczególną uwage poświęcono językowi niemieckiemu, który planowano ustanowić językiem roboczym w administracji. Postanowiono także, iż Związek wystawi swoich kandydatów do wyborów do Komitetu Ustawodawczego i komitetów lokalnych. Kandydatami do komitetu guberni chersońskiej wyznaczono barona Meierdorfa i pastora Winklera, a do odeskiego komitetu ziemskiego: W. Reisicha i Pfaffa z kolonii Großliebental, G. Taubergera z kolonii Kuczugan, Flammera z kolonii Neufriedental i L. Reicherta z kolonii Berezań. Oprócz tego zdecydowano, iż będą wydawane dwie gazety związkowe: "Wochenblatt" i "Vereinszeitung" oraz kalendarz związkowy na 1918 r. „Vereinskalender”. Wybory do Komitetu Ustawodawczego nie przyniosły oczekiwanych rezultatów - nie wybrano ani jednego kandydata związku. Następnie Komitet Ustawodawczy został rozpędzony przez bolszewików. W Kijowie utworzono Ukraińską Centralną Radę, a w Charkowie ogłoszono Ukraińską SRR. W Sewastopolu, Jekaterynosławiu, Odessie i Kijowie wybuchły antybolszewickie powstania ${ }^{55}$.

Niemieckie powstanie skierowane przeciwko władzy bolszewickiej rozpoczęło się w kwietniu 1919 r. w kolonii Großliebental. Podobnie jak pozostałe powstania zostało spowodowane masowym wywozem żywności, rekwizycjami koni i dobytku ${ }^{56}$. W związku z tym, iż wzięła w nim udział także ludność bułgarska i ukraińska, objęło ono swym zasięgiem wszystkie kolonie otaczające Odessę oraz przedmieścia miasta. W celu stłumienia powstania została utworzona Rada Obrony Okręgu Odeskiego, na której czele stali bolszewicy. W sierpniu przeciwko powstańcom wystąpiły oddziały Armii Czerwonej. Główna bitwa odbyła się 4-5 sierpnia pod miejscowością Wielika Askarża. Powstańcy doznali w niej porażki, po czym poszczególne kolonie zaczęły się poddawać. Mimo to powstanie trwało jeszcze do 1921 r. ${ }^{57}$ Skutkiem powstania była jeszcze surowsza polityka władz

\section{......}

54 T. Penter, Odessa 1917: Revolution an der Peripherie, s. 66.

55 E.G. Plesskaya-Zebol'd, Odesskije Nemcy 1803-1920, s. 347, 357

56 E.G. Plesskaya-Zebol'd, Nemcy Pričernomorja: istoria i kultura. XIX-XX wW., w: Nemcy Pričernomorja, Odessa 2003 , s. 11

57 J.W. Kotljar, Nimecke naselenja piwdnia Ukrainy u powstanskomy rusi selian (1919-1920 rr.), w: Materialy Mežnarodnoj naučnoj konferencii poswiaščenoj 200-letju pereselenja nemcew w Krym - Istoria nemeckoj kolonizacji w Krymu i na jugie Ukrainy w XIX-XX ww., Symferopol 2007, s. 284-289. 
wobec kolonistów niemieckich, której towarzyszyły konfiskaty żywności. Działania te i dodatkowo susza lat 1921-1923 stały się przyczyną wielkiego głodu.

Ostatecznie władza bolszewicka została ustanowiona w Odessie w lutym 1920 r. Zgodnie z zasadą równości wszystkich narodów jeszcze przed tym wydarzeniem, bo już w maju 1919 r., utworzono tu oddział niemiecki przy Odeskim Gubernialnym Komitecie Rewolucyjnym. W czerwcu tego samego roku powstał Odeski Komitet Rewolucyjny Niemieckich Kolonistów i Robotników. Utworzono w nim dwie sekcje: kulturalno-edukacyjną i społeczną. Następnie w lutym 1920 r., zgodnie z rozporządzeniem Odeskiego Gubernialnego Biura KPU(b), przy Biurze Informacyjnym KPU(b) w Odessie została założona sekcja niemiecka. Jej zadaniem było popularyzowanie idei komunistycznych w byłych koloniach niemieckich. W tym celu przygotowywano broszury informacyjne w języku niemieckim oraz wydano 28 numerów gazety „Der Pflug” („Pług”). Za działalność agitacyjną wśród Niemców zamieszkujących Odessę odpowiedzialna była niemiecka komisja przy Biurze Informacyjnym KPU(b), wydająca gazety "Hammer und Pflug” ("Młot i Pług”) i "Die Arbeit" („Praca”). W 1925 r. do partii liczącej 5265 osób należało tylko 44 Niemców, co stanowiło 0,8\% wszystkich członków. W wyniku działań komisji niemieckiej przybyło ich niewielu więcej, gdyż spośród 5500 Niemców zamieszkujących Odessę udało się zwerbować do partii tylko 2 robotników. Lepsze rezultaty osiągnęła sekcja niemiecka na prowincji, pozyskując do partii 46 nowych członków - niemieckich kolonistów ${ }^{58}$.

W celu przygotowania niemieckich pedagogów-kolektywistów do pracy w szkołach i przedszkolach w 1924 r. przy Odeskim Instytucie Oświaty (Odesskij Institut Narodnowo Obrazowannja) otwarto sektor niemiecki. W 1934 r. został on przekształcony w Odeski Niemiecki Instytut Pedagogiczny (Odessaer Deutsches Pädagogisches Institut). Była to jedyna na Ukrainie niemiecka placówka pedagogiczna tego typu. Znajdowały się tu następujące wydziały: historyczny, filologiczny, matematyczno-fizyczny, biologiczno-chemiczny i geograficzny. Instytut nie rozwiązał jednak problemu braku kadr do nauczania niemieckich dzieci, a w wyniku wewnętrznej walki z wrogami narodu, atmosfery podejrzliwości i donosicielstwa Instytut zaczęto uważać za centrum działalności kontrrewolucyjnej faszystów i trockistów. W 1934 r. o działalność kontrrewolucyjną zostali oskarżeni profesorowie Instytutu R.K. Mikwitz (wykładowca historii literatury niemieckiej) i A.N. Strem (nauczyciel języka niemieckiego). W wyniku prowadzenia takiej polityki kadrowej Instytut tracił dobrych wykładowców, a pozyskać nowych nie było łatwo ${ }^{59}$.

W latach dwudziestych utworzono w Odessie związek niemiecki Kulturverein, w ramach którego działało kółko teatralne. W 1933 r. na jego bazie utworzono Niemiecki Teatr Robotniczo-Kołchoźniczy. W trakcie swojego istnienia teatr miał kilka różnych nazw: Nimeckij teatr w Odesi, Gosudarstwennyj nemeckij teatr, Ukrainisches Staatliches deutsches Rollettibistentheater i ostatecznie Nemeckij raboče-kolhoznyj teatr. Jako głównego reżysera zatrudniono I.W. Schmidta z Berlina. Dyrektorem teatru został A.G. Geft, którego zasługą było założenie w teatrze orkiestry. W 1937 r. teatr zdobył trzecie miejsce na Pierwszym Republikańskim Robotniczo-Kołchoźniczym Przeglądzie Teatrów Robotniczo-Chłopskich i nagrodę w wysokości 4000 karbowańców. W 1934 r. zaszły wielkie zmiany w polityce narodowościowej na Ukrainie. Komitet Centralny partii komunistycznej

\section{......}

58 E.A. Salončuk, Dejatelnost' nemeckih sekcyj pri partyjnych i ispolnitiejnych komitetach Odesskoj gubernii i okruga (1920-1928 gg.), w: Nemcy Odessy i odesskogo regiona, s. 252-265; W.W. Solovova, Interkluby w Odessie (20-30-e gg XX w.), w: Nemcy Odessy i odesskogo regiona, s. 321.

59 E.G. Plesskaya-Zebol'd, Nemeckaja škola w internacjonalnom okruženji, w: Etničeskije soobščestwa Ukrainy: istoria, sowremennost', budušče, Donieck 2006, s. 237; E.G. Plesskaya-Zebol'd, Podgotowka nacjonalnych pedagogičeskich kadrow dla nemeckich škol Ukrainy (1924-1938gg.) , w: Nemcy Odessy i odesskogo regiona, s. 287-305. 
podjął decyzję o walce z "kontrrewolucyjnym faszystowskim elementem” w niemieckich koloniach. Ochronę kultur narodowych zaczęto postrzegać jako „zagrożenie dla kultury rdzennej ludności". Posługiwanie się językiem niemieckim w szkołach i innych instytucjach przedstawiano jako germanizację ludności rosyjskiej i ukraińskiej. W wyniku tego w 1938 r. niemiecki teatr oraz Instytut Pedagogiczny zostały zamknięte ${ }^{60}$. W okreggu odeskim aresztowano 800 osób oskarżanych o przynależność do organizacji faszystowskich ${ }^{61}$.

W trakcie II wojny światowej Odessa znalazła się pod niemiecko-rumuńską okupacją i weszła w skład Transnistrii - terenu będącego częścią okupowanego terytorium Ukrainy i Mołdawii, położonego między Dniestrem i Bugiem. Znajdował się on pod zarządem rumuńskim. Gubernatorem Transnistrii został rumuński profesor G. Aleksianu, a stolicą była Odessa. Ogółem w Transnistrii mieszkało 130 000-135 000 Niemców. Ludność niemiecka została jednak wyłączona spod administracji rumuńskiej. Objęto ją kontrolą specjalnie w tym celu utworzonej służby rejestracji etnicznych Niemców - Volksdeutsche Mittelstelle (Vomi). Jej centrum znajdowało się w kolonii Landau. Vomi zajęła się organizacją niemieckiego szkolnictwa i życia kulturalnego. Głównym jej celem było jednak pobieranie podatków od ludności niemieckiej w formie połowy rocznego dochodu oraz dostaw żywności na potrzeby Rzeszy i niemieckiej armii. Przy rejestracji większości volksdeutschy przyznano trzecią - najniższą kategorię etniczną. Głównym powodem tego była słaba znajomość języka niemieckiego lub często całkowity jej brak. Zaszeregowanie do tej kategorii nie dawało Volksdeutschom możliwości uzyskania obywatelstwa Rzeszy. Wyjątek stanowity osoby, które służyły w Wehrmachcie, wojskach SS i niemieckiej policji62.

Do pracy z młodymi volksdeutschami została stworzona organizacja Niemiecka Młodzież Transnistrii wzorowana na Hitlerjugend. Należeli do niej chłopcy urodzeni w latach 1926-1933 i dziewczynki w latach 1923-1933. Na terytorium Transnistrii wznowity dziatalność niemieckie szkoły. Utworzono seminaria nauczycielskie w miejscowościach Selz i Prischib. Wykwalifikowani nauczyciele otrzymali z kolei możliwość uczestnictwa w specjalnych kursach organizowanych w Niemczech. Imprezy kulturalne dla volksdeutschy organizowano w Domu Niemieckim w Odessie. Odbywały się tu pokazy filmów, przedstawienia teatralne i wieczory poetyckie. 7 grudnia 1943 r. otwarto w Odessie uniwersytet, a jednym z jego prorektorów został volksdeutsch o nazwisku Schettle. Podjęto także próbę wznowienia wydawania gazety "Odessaer Zeitung" oraz nowego pisma pt. "Niemiec w Transnistrii" („Der Deutsche in Transnistrien") ${ }^{63}$

Na początku 1944 r., wraz z wycofywaniem się wojsk niemieckich, volksdeutsche zostali także zmuszeni do ucieczki - początkowo na tereny Polski, a następnie do Niemiec. Po wojnie część z nich tam została, a część deportowano z powrotem do ZSRR i wysłano na Syberię, do Kazachstanu i innych republik Azji Centralnej64. W opuszczonych przez nich gospodarstwach w 1944 r. ulokowano m.in. przesiedlonych z Kazachstanu, Uralu i Syberii obywateli polskich ${ }^{65}$. Następnie dołączyli do nich także Ukraińcy objęci podpisaną 9 września 1944 r. w Warszawie umową pomiędzy Polskim Komitetem Wyzwolenia Narodowego

60 W.W. Solovova, Odesskij nemeckij paboče-kolchoznyj teatr: istoki i stanowlenje, w: Nemcy Odessy i odesskogo regiona, s. 306-318; W.W. Solovova, Interkluby w Odessie, s. 321

61 G. Sticker, Deutsche Geschichte im Osten Europas. Russland, Berlin 1997, s. 206

62 E.G. Plesskaya-Zebol'd, Die Transnistriendeutschen, w: Transnistrien und Odessa, red. E. Völkl, Regensburg 1996, s. 88-91.

63 E.G. Plesskaya-Zebol'd, Nemcy Pričernomorja: istoria i kultura. XIX-XX ww., w: Nemcy Pričernomorja, s. 5.

64 N.A. Ševčuk, Etničeskije Nemcy w Transnistrii (1941-944 gg.), w: Nemcy Odessy i odesskogo regiona, S. 355-372.

65 G. Hryciuk, Przesiedlency - byli zestańcy i uciekinierzy w obwodzie chersońskim w latach 1944-1946, w: Polacy na potudniowej Ukrainie i Krymie, s. 167. 
a rządem Ukraińskiej SRR o wymianie ludności66. Działania te przyczyniły się do tego, iż przez całe dziesięciolecia Niemców w Odessie prawie nie było. Zgodnie z ukazem Prezydium Rady Najwyższej ZSRR z listopada 1948 r. i grudnia 1950 r. deportowani Niemcy byli pozbawieni prawa powrotu do wcześniejszego miejsca zamieszkania. Ograniczenia te zniesiono dopiero $\mathrm{w}$ listopadzie 1972 r. ${ }^{67}$, a w praktyce powrót był możliwy dopiero na początku lat 90.

\section{OBECNA SYTUACJA NIEMCÓW W ODESSIE}

Polityka deportacji i przesiedleń sprawiła, że liczba ludności niemieckiej uległa znacznemu zmniejszeniu. W trakcie spisu ludności z 1989 r. narodowość niemiecką zadeklarowało tylko 4000 osób. Społeczność ta powoli zaczęła się odradzać. Na początku lat 90., w związku z utworzeniem Funduszu Ukraińsko-Niemieckiego, rozpoczęła się akcja powrotów Niemców deportowanych na Syberię, do Kazachstanu i innych republik Azji Środkowej. Z wielu przyczyn nie nabrała ona jednak oczekiwanego rozmachu. Te osoby, które zdecydowały się wrócić, zamieszkują miejscowości takie, jak: Petrodolinskoje (wcześniejsza Peterstal), Dobroaleksandriwka (Aleksanderhilf) i Nowogradowka (Neuburg). Najwięcej Niemców jest obecnie we wsi Kudriawka, która jednak wcześniej nie była niemiecką kolonią ${ }^{68}$. Jest to miejscowość zaprojektowana przez niemieckiego doktora, Waffenschmidta, i specjalnie założona w ukraińskim stepie w celu osiedlenia tu niemieckich przesiedleńców z republik azjatyckich. Jej lokalizacja okazała się jednak niezbyt fortunna dla samych zainteresowanych ${ }^{69}$.

Potomkowie ukraińskich i rosyjskich Niemców, którzy przybyli do Odessy, w 1989 r. utworzyli tu towarzystwo Wiedergeburt (Odrodzenie). Od 1991 r. ma ono filie w całej Ukrainie. Jego prezesem od samego początku jest Aleksander Wergiliewicz Jungmeister. Początkowo spotkania Towarzystwa odbywały się w wynajmowanych pomieszczeniach. Następnie członkowie tej organizacji utworzyli w Odessie niemiecką parafię ewangelickoluterańską i zarejestrowali ją 16 października 1990 r. W ten sposób odeska parafia została pierwszą luterańską wspólnotą na Ukrainie założoną po pierestrojce i z tego względu obrano ją na siedzibę Niemieckiego Kościoła Ewangelicko-Luterańskiego Ukrainy. Pierwszym pastorem został Wiktor Grefenstein, który kierował wspólnotą do 1995 r. W 1992 r. został on także zwierzchnikiem wszystkich nowo powstałych parafii luterańskich na Ukrainie ${ }^{70}$. Następnie na stanowisku zwierzchnika diecezji zastąpił Grefensteina pochodzący z Bawarii biskup Ratz. Przy kościele pracuje także pastor Gross, Niemiec przybyły do Odessy z Kaukazu. Wychował się on w rodzinie ateistycznej, ale w wieku 16 lat nawrócit się i zdecydował się zostać pastorem ${ }^{71}$.

Od momentu odrodzenia wspólnota nie posiadała własnych pomieszczeń. Przez przeszło 10 lat musiano wynajmować salę w celu odprawienia nabożeństwa. Zajęcia biblijne

\section{-....}

66 J. Pisuliński, Przesiedlenie ludności ukraińskiej z Polski na południe USRR 1944-1945, w: Polacy na południowej Ukrainie i Krymie, s. 182.

67 A.N. Keller, Izmienienja w nemeckoj toponimi odesskovo regiona, w: Nemcy Odessy i odesskogo regiona, s. 349-350.

68 Tamże, s. 354

69 K.-M. Gauß, Niemcy, s. 242.

70 Cerkownyj centr sw. Pawla. Odessa, red. K.-J. Ropke, Odessa-Monachium 2002, s. 18; N. Helling, B. Schulze, Invitation to Odessa. Guide to Ukraine, s. 16

71 K.-M. Gauß, Niemcy, s. 205. 
odbywały się w niewielkim pomieszczeniu kancelarii, a zajęcia z młodzieżą w mieszkaniu pastora. Wobec tego już w 1992 r. parafia rozpoczęła starania o odzyskanie działki kościelnej, ze znajdującą się na niej ruiną spalonego w 1975 r. kościoła św. Pawła i sąsiadującego z nią budynku wybudowanego w XIX w. jako przytułek dla starców. 23 października 1996 r. ruina kościoła wraz z przylegającym terenem została zwrócona wspólnocie. Jesienią 2002 r. w odrestaurowanym budynku przytułku dla starców został otwarty dom pastorski, w którym mieści się Centrum Kościelne św. Pawła (Cerkownyj centr sw. Pawla). Znajdują się tam: ośrodek administracyjny Kościoła luterańskiego, pomieszczenia seminaryjne i kilka pokoi gościnnych ${ }^{72}$. Odbudowę samego kościoła rozpoczęto w 2006 r. $^{73}$ Wspólnota ściśle współpracuje z Kościołem luterańskim w Niemczech, który dostarcza funduszy na remont budynku oraz udziela wsparcia w organizacji letnich obozów biblijnych dla dzieci ${ }^{74}$. Ogólnie można stwierdzić, że do wspólnoty należą dwa typy wiernych: pierwsi to tacy, którzy są luteranami od zawsze, a drudzy dopiero się nimi stali. Chodzi tu o wiernych z Kazachstanu, którzy w mniejszym stopniu szukają wspólnoty chrześcijańskiej ze względu na wewnętrzną potrzebę uczestnictwa we mszy świętej. W większym zaś liczą na pomoc Kościoła w dotarciu do Niemiec ${ }^{75}$.

Skutkiem odrodzenia niemieckiej wspólnoty było także powstanie w Odessie Domu Bawarskiego w 1993 r. Jest to niemieckie centrum kultury, w ramach którego działają ukraińskie i niemieckie instytucje ${ }^{76}$. Zostało otwarte przy wsparciu bawarskiego ministerstwa spraw społecznych (Bayerisches Sozial Ministerium) i Kościoła ewangelickiego. Służy ono jako centrum społeczne i centrum nauki języka niemieckiego. We współpracy z Instytutem Goethego są tu prowadzone komercyjne kursy języka niemieckiego dla około tysiąca słuchaczy rocznie ${ }^{77}$.

Dodatkowym zadaniem Domu Bawarskiego jest pogłębianie kontaktów kulturalnych między Niemcami a Ukrainą, jak również niesienie pomocy niemieckim przesiedleńcom z Kazachstanu, Tadżykistanu i innych republik ZSRR, którzy po ogłoszeniu przez Ukrainę niepodległości byli zachęcani do powrotu w dawne strony rodzinne. Dom Bawarski miał za zadanie pomagać im materialnie i logistycznie, czyli znaleźć dla nich miejsce zamieszkania, otwierać zakłady przemysłowe i pogłębiać więzi kulturalne wśród niemieckiej społeczności. Ważnym punktem działalności stała się nauka języka niemieckiego, w którym dzieci i wnukowie deportowanych mówiły przeważnie słabo albo w ogóle go nie znały. Repatrianci chętnie korzystali i korzystają z tej pomocy, wolą jednak przy pierwszej nadarzającej się okazji opuścić Ukrainę i wyemigrować do Niemiec ${ }^{78}$.

Dom Bawarski i Kościół ewangelicko-luterański wspólnie utrzymują w miejscowości Nowogradowka oddalonej o $10 \mathrm{~km}$ od Odessy filię placówki pomocy społecznej. Placówkę tę prowadzi siostra Doris, diakonisa z Niemiec. Pełni ona funkcje duszpasterskie oraz jest pielęgniarką i pracownikiem społecznym w jednej osobie. Pod jej opieką znajdują się miejscowości Nowogradowka, Dobroaleksandrowka i Marianowka. Zamieszkują je głównie starcy oraz kilkadziesiąt rodzin przybyłych w ciągu ostatnich 10 lat z Kazachstanu. W celu opieki nad nimi zostało utworzone towarzystwo Gesellschaft für Technische Zusammenarbeit (Towarzystwo Współpracy Technicznej), które współpracuje z rządem niemieckim i zajmuje się m.in. budową domów dla niemieckich przesiedleńców z republik

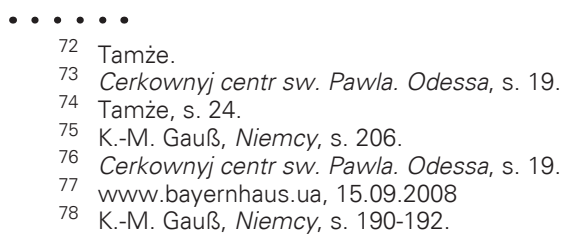


azjatyckich ${ }^{79}$. W miejscowości Petrodolinskoje wybudowano takich domów 40. Są one skromne, ale zapewniają podstawowy komfort sanitarny ${ }^{80}$. Oprócz tego Towarzystwo Współpracy Technicznej wspiera dotacjami inne projekty społeczne, m.in. projekty mające na celu pobudzenie przedsiębiorczości wśród Niemców na Ukrainie, czego przykładem może być zakład stolarski przybyłego z Kazachstanu Iwana Lewila we wsi Petrodolinskoje. Jest on jednak jednym z niewielu, którym się udało. Niemieckich robotników u siebie nie zatrudnia, gdyż według niego są leniwi i woli nająć do pracy Ukraińca lub Rosjanina. Sporo osób także zaprzepaszcza okazane im wsparcie, sprzedając otrzymane od TWT domy i emigrując do Niemiec ${ }^{81}$.

Ciekawą osobą, której warto poświęcić więcej uwagi jest wcześniej już wspomniany Aleksander Wergiliewicz Jungmeister - prezes odeskiej filii towarzystwa Wiedergeburt. Urodził się on w Odessie, jego matka pochodziła z austriackiej rodziny z Czech, a ojciec z Rygi, z Niemców nadbałtyckich. Oboje mówili po niemiecku. Na skutek urzędowej pomyłki w paszporcie jego matki widniał wpis „Rosjanka”, ojcu natomiast wpisano zgodnie ze stanem faktycznym "Niemiec". W wyniku tego rodzina została rozdzielona, gdyż ojca w 1938 r. zesłano do obozu w Archangielsku, a matce pozwolono zostać z synem w Odessie. Ojciec, deportowany nauczyciel akademicki niemieckiego pochodzenia został w łagrze przyuczony do zawodu robotnika zakładów zbrojeniowych. W czasie okupacji miasta pozostałą tu matkę poddano germanizacji, wskutek czego jej sytuacja po wojnie radykalnie się zmieniła. O ile wcześniej jako Rosjanka nie była podejrzana w oczach władz, to po wojnie jako domniemana Niemka stała się obiektem szykan ze strony służby bezpieczeństwa. Tymczasem ojciec, wysłany na roboty przymusowe z powodu swojego podejrzanego pochodzenia, zyskiwał jako członek klasy pracującej coraz więcej proletariackich praw. Dlatego rodzice postanowili, że syn przeprowadzi się do ojca, do zamkniętego rejonu Taszkientu. Stamtąd wiele lat później wrócił na Ukrainę, aby nauczać w różnych gimnazjach na Krymie, w Besarabii i wreszcie w Odessie ${ }^{82}$. W ten oto sposób wspólna niemiecka narodowość przyczyniła się do rozdzielenia jego rodziny.

Obecnie jednym z zajęć A. Jungmeistra jest opieka nad cmentarzem wojskowym, który na mapie miasta figuruje pod nazwą „Cmentarz niemiecki”. Na cmentarzu tym nie są jednak pochowani zamieszkujący kiedyś to miasto Niemcy. Ich groby znajdują się na cmentarzu miejskim i są do tego stopnia zaniedbane i zapomniane, iż trudno je znaleźć. Pod nazwą "cmentarz niemiecki w Odessie", kryje się cmentarz wojskowy. Na nim według zamierzenia A. Jungmeistra mieliby spocząć żołnierze polegli w pierwszej wojnie światowej, a na kamieniach nagrobnych widniałyby napisy w 17 językach narodowości żołnierzy. A. Jungmeister wraz z kilkoma pomocnikami organizuje ten cmentarz od kilku lat. Ustawił już nagrobki z nazwiskami niemieckimi, polskimi, gruzińskimi, ukraińskimi, węgierskimi, włoskimi, czeskimi, rosyjskimi, ormiańskimi i rumuńskimi ${ }^{33}$. W pracy nad tym dziełem wspiera go niemieckie towarzystwo Volksbund Deutsche Kriegsgräberfürsorge z siedzibą w Kassel. Cmentarz odwiedzają rodziny zmarłych i przedstawiciele państw, z których pochodziły pochowane na cmentarzu osoby, m.in. przedstawiciele władz polskich.

Towarzystwo Wiedergeburt liczy obecnie około 300 członków, a jego biuro znajduje się w domu parafialnym przy kościele św. Pawła. Głównym pragnieniem jego członków jest to, aby wreszcie uznano, że nie tworzyli oni piątej kolumny Hitlera. Powstało tam tak-

79 J. Bauman, U. Moosburger, Odessa Facetten einer Stadt im Wandel, Regensburg 2003, s. 99

80 K.-M. Gauß, Niemcy, s. 228

81 Tamże, s. 226-227.

82 Tamże, s. 200-201.

83 Tamże, s. 190-192. 
że stowarzyszenie konkurencyjne dla Wiedergeburt o nazwie Assoziation der Deutschen in der Ukraine (Stowarzyszenie Niemców na Ukrainie). Organizacje te są ze sobą w konflikcie. Jednak nie dzielą ich różnice merytoryczne czy ideologiczne, lecz raczej osobiste kłótnie i niechęci ${ }^{84}$.

Jak widać, historia nie oszczędzała społeczności niemieckiej w Odessie. Jej dzieje były bardzo dramatyczne i burzliwe. Dziś panują wśród nich gtównie uczucia zniechęcenia i zawodu. Czują się w dużej mierze oszukani przez rząd niemiecki, który robi duże problemy osobom chcącym przesiedlić się do tego kraju. W społeczeństwie ukraińskim też nie czują się dobrze. Wielu jest zdania, iż w Kazachstanie czy Kirgizji żyło im się lepiej niż na Ukrainie, jednak musieli wyjechać ze względu na nasilający się kazachski i kirgiski nacjonalizm, w wyniku którego nie czuli się tam bezpiecznie ${ }^{85}$. Na Ukrainie natomiast nie chcą zostać, a do Niemiec wyjechać nie mogą. Z ich ust padają zgorzkniałe wypowiedzi: „W Kirgizji wszystko było o wiele piękniejsze niż tutaj, ale ci przeklęci Ukraińcy nas tu zwabili, a przeklęci Niemcy zatroszczyli się o to, żebyśmy już nigdy nie mogli się stąd wydostać" 86 lub "Nie chcą nas ani tu ani tam"87. Nie zmienia to jednak roli, jaką odegrali w życiu gospodarczym i społecznym miasta, a była ona znacząca.

BIBLIOGRAFIA

Bauman J., Moosburger U., Odessa. Facetten einer Stadt im Wandel, Regensburg 2003.

Brandes D., German Colonists in Southern Ukraine up to the Repeal of the Colonial Statute, w: German-Ukrainian Relations in Historical Perspective, red. Torke H.-J., Himka J.-P., Edmonton-Toronto 1994.

- Von den Zaren adoptiert. Die deutschen Kolonisten und Balkansiedler in Neurußland und Bessarabien 1751-1914, Oldenburg Verlag, München 1993.

Cerkownyj centr sw. Pawla. Odessa, red. Ropke K.-J., Odessa-Monachium 2002.

Cygański M., Niemieckie mniejszości narodowe w państwach Europy Środkowo-Wschodniej w latach 1945-1995, Opole 2000.

Deutsche und deutsche Kultur in der Ukraine, red. Smolij W., Kijów 2008.

Dobroer A., Religioznoe služenje pol'skich sviaščennikov v južnoj Ukrainie, red. Ciesielski T., Czapiewski E., Korytko A., Kusznir W., Stroński H., Polacy na Południowej Ukrainie XVII-XVIII wiek, Olsztyn-Opole-Wrocław-Odessa 2006.

Gauß K.-M., Niemcy na peryferiach Europy. Wedrówki przez Litwee, Spisz i brzegiem Morza Czarnego, Wołowiec 2000.

Grossman A., Krym. Pótwysep rozmaitości ... oraz Lwów, Kijów Odessa, Kraków 2007.

Helling N., Schulze B., Invitation to Odessa. Guide to Ukraine, 2005.

Hryciuk G., Przesiedleńcy - byli zesłańcy i uciekinierzy w obwodzie chersońskim w latach 1944-1946, w: Polacy na południowej Ukrainie i Krymie, red. Ciesielski T., Czapiewski E., Kusznir W., Odessa-Opole-Wrocław 2007.

Iwanowa T., Nimecka kolonizacja pivdennovo pričernomorja, w: Region nadczarnomorski w polityce europejskiej, red. Ciesielski T., Czapiewski E., Kusznik, W., Odessa-OpoleWrocław 2008.

84 Tamże, s. 196-199

85 Tamże, s. 230.

86 Tamże.

87 Wypowiedź jednej z członkiń towarzystwa Wiedergeburt, badania własne z wizyty w Odessie. 
Kappeler A., Kleine Geschichte der Ukraine, München 1994.

Keller A.N., Izmienienja w nemeckoj toponimi Odesskovo regiona, w: Nemcy odessy i odesskogo regiona, red. Plesskaya-Zebol'd E.G., Odessa 2003.

Kotljar J.W., Nimecke naselenja piwdnia Ukrainy u powstanskomy rusi selian (1919-1920 rr.), w: Materialy Mežnarodnoj naučnoj konferencii poswiaščenoj 200-letju pereselenja nemcew w Krym - Istoria nemeckoj kolonizacji w Krymu i na jugie Ukrainy wXIX-XX ww., Symferopol 2007.

Penter T., Odessa 1917: Revolution an der Peripherie, Köln-Böhlau 2000.

Pisuliński J., Przesiedlenie ludności ukraińskiej z Polski na południe USRR 1944-1945, w: Polacy na południowej Ukrainie i Krymie, red. Ciesielski T., Czapiewski E., Kusznir W., Odessa-Opole-Wrocław 2007.

Plesskaya-Zebol'd E.G. Die Transnistriendeutschen, w: Transnistrien und Odessa, red. Völkl E., Regensburg 1996.

-, Nemeckaja škola w internacjonalnom okruženji, w: Etničeskije soobščestwa Ukrainy: istoria, sowremennost', budušče, Donieck 2006.

-, Nemcy w Pričernomorja: istoria i kultura. XIX-XX wW., w: Nemcy Pričernomorja, Odessa 2003.

-, Odesskije Niemcy 1803-1920, Odessa 1999.

- Podgotowka nacjonalnych pedagogičeskich kadrow dla nemeckich škol Ukrainy (19241938 gg.), w: Niemcy Odessy i odesskogo regiona, red. Plesskaya-Zebol'd E.G., Odessa 2003.

- Wkład Niemcev v promyszlennoje razwitje Odessy s popytkoj rassmotrenja kulturologiceskogo aspektu problemy, w: Niemcy Odessy i odesskogo regiona, red. PlesskayaZebol'd E.G., Odessa 2003.

Salončuk E.A., Dejatelnost' nemeckih sekcyj pri partyjnych $i$ ispolnitiejnych komitetach Odesskoj gubernii i okruga (1920-1928 gg.), w: Niemcy Odessy i odesskogo regiona, red. Plesskaya-Zebol'd E.G, Odessa 2003.

Sevčuk N.A., Die Deutsche evangelisch-lutherische Gemeinde Odessas im 19. Jahrhundert, w: Odessa. Kapitel aus Kulturgeschichte, red. Schmalzl Ch., Regensburg 1998.

Skrypt do zajęć: Zagadnienia narodowościowe Europy Środkowej i Bałkanów, Kowalski M., Studium Europy Wschodniej.

Solovova W.W. Interkluby w Odessie (20-30-e gg XX w.), w: Niemcy Odessy i odesskogo regiona, red. Plesskaya-Zebol'd E.G, Odessa 2003.

Sticker G., Deutsche Geschichte im Osten Europas. Russland, Berlin 1997.

Topij A., Ludność niemiecka wobec rusyfikacji guberni bałtyckich 1882-1905, Bydgoszcz 1997.

Trąbski M., Odessa i stepy Nowej Rosji opisane przez Juliana Ursyna Niemcewicza w 1818 r., w: Polacy na południowej Ukrainie i Krymie, red. Ciesielski T., Czapiewski E., Kusznir W., Odessa-Opole-Wrocław-Olsztyn 2007.

Zasztowt L., Zsyłka i przesiedlenia ludności polskiej z zachodnich guberni w głąb cesarstwa rosyjskiego po postaniu styczniowym, "Przegląd Wschodni”, Warszawa 1998, z. 2(18)

Zieliński Z., Niemcy. Zarys dziejów, Warszawa 1998.

ŹRÓDŁA INTERNETOWE

Www.bayernhaus.ua, 15.09.2008 


\section{Summary}

In this work the history of German minority in the Ukrainian city of Odessa has been presented from the beginning of the $18^{\text {th }}$ century till the present times. An important aspect of this work is to show the two dimensions of German colonization of Ukrainian territories which was concurrently inhabited by the representatives of German intelligence and German entrepreneurs in the cities, as well as by German peasants in the country. As this work shows the history of Germans in Ukraine began with being granted a privileged status and finished with losing it and being dispossessed during the First and Second World Wars.

The paper starts with a brief description of the German nation and its expansion to the East. Then the history of the German colonization of Odessa is presented including the religious life of this group, the role Germans played in the economy of the city and its surroundings. After that attention is focused on the damage inflicted to the community during two world wars which led to the fact that Germans were deprived of their rights and marginalized. The last section concentrates on the present situation of German minority in Odessa.

Keywords: Odessa, Germans, Ukraine, privileged status, humiliation 